\title{
Způsoby financování výstavby jaderných elektráren a jejich hrozby ${ }^{1}$
}

\section{Ways of Financing the Construction of New Nuclear Power Plants and the Threats Associated with Them}

\author{
TOMÁŠ DRÁB, TOMÁŠ VLČEK ${ }^{2}$
}

\begin{abstract}
The paper deals with the financing of new nuclear power plants. After a period of stagnation and decline, nuclear energy is regaining approval in the EU, as some member states are constructing or preparing to construct new nuclear power plants. Yet the development of new facilities is facing enormous challenges. One of the most significant challenges is the very costly financing of nuclear projects. This paper analyses the methods of financing new nuclear projects and attempts to offer a classification of possible financing schemes; then, on the basis of such a classification, it tries to identify the threats attached to particular schemes that states face when deciding to develop nuclear projects. The threats were derived from an analysis of the investment process and from the identification of participants in nuclear investments and their relations. The analysis reveals a greater set of threats when foreign and private entities are involved in financing. The relevance of threats and the associated risks, however, must be assessed in the context of each particular nuclear project.
\end{abstract}

Keywords: nuclear energy; nuclear new build; financing; risks; financing models; European Union

\section{1. Úvod}

Jaderná energie (JE) představuje stabilně druhý nejdůležitější zdroj elektřiny v Evropské Unii (EU) v těsném závěsu za uhlím. Z celkové elektroenergetické produkce zemí Unie ve výši necelých 3300 TWh ročně zajišt’uje kolem 900 TWh

1 Text vznikl v rámci specifických projektů Masarykovy univerzity „Evropa v měnícím se mezinárodním prostředí II“ (MUNI/A/1113/2015) a „Behaviorální, znalostní a ekonomické aspekty oceňování a obchodování finančních a jiných aktiv“ (MUNI/A/0823/2016).

2 Tomáš Dráb: Katedra financí, Ekonomicko-správní fakulta, Masarykova Univerzita, Lipová 41a, 602 00, Brno / Department of Finance, Faculty of Economics and Administration, Masaryk University, Brno, Czech Republic. E-mail: 321854@mail.muni.cz.

Tomáš Vlček: Katedra mezinárodních vztahů a evropských studií, Fakulta sociálních studií, Masarykova Univerzita, Joštova 10, 60200 Brno / Faculty of Social Studies, Masaryk University, Brno, Czech Republic. E-mail: tomas.vlcek@mail.muni.cz 
(IEA n.d.). Jaderná energie se však na rozdíl od uhlí využívá téměř výhradně $\mathrm{k}$ výrobě elektřiny s dosud zcela zanedbatelným využíváním odpadního tepla. JE je kontroverzním tématem $\mathrm{v}$ rozličných společensko-politických rovinách a její získávání představuje náročný proces jak z hlediska technologického a bezpečnostního, tak i finančního, přičemž všechny tyto aspekty jsou navzájem propojeny. $V$ těchto měŕítkách není s JE srovnatelný žádný jiný energetický zdroj, a to jak v objektivně pozitivním, tak negativním smyslu. Energetická hustota uranu je 2,3 milionkrát větší než v případě uhlí (Osička, Černoch, Ocelík a Vlček 2014: 163), provoz jaderné elektrárny je bezemisní a objem kumulativní výroby elektrriny je s ohledem na zastavěnou plochu velmi vysoký (v roce 2015 měly nově stavěné jaderné bloky průměrný instalovaný výkon 976 MW; Schneider et al. 2016: 28). Na druhou stranu, investiční náklady na výstavbu jaderné elektrárny jsou mimořádně vysoké, v zemích OECD dosahují hodnoty od 2021 USD/kW v Jižní Koreji do 6215 USD/kW v Mad’arsku (WNA 2017). Pro srovnání, průměrné investiční náklady elektrárny s paroplynovým cyklem činí 718 USD/kW; pro uhelnou elektrárnu jde o 2010 USD/kW (US Department of Energy 2013: 9) Výstavba většiny stavěných jaderných elektráren na světě je navíc zpožděna a oproti plánu operuje se zvýšenými náklady, což je pro jadernou energetiku endemický problém (Vlček, Jirušek a Henderson 2015: 482-483)

Přes mnohé kontroverze a nesnáze, které ji provázejí, se JE těší v mnoha zemích EU obnovené vlně zájmu. Tento trend je zaprúíčiněn více faktory, přičemž za nejvýznamnější můžeme považovat akcelerující environmentální politiku EU, jež klade důraz na snižování emisí skleníkových plynů, dosluhování a odstavování starších jaderných zdrojů, které hrozí ve střednědobém horizontu způsobit nedostatek elektřiny, a také principiální neschopnost obnovitelných zdrojů fungovat v základním zatížení sítě.

Po fázi hlubokého útlumu budování jaderných kapacit v EU, kterou můžeme dokumentovat skutečností, že dosud poslední reaktor uvedený v EU do provozu byl spuštěn roku 2007, se i přes havárii ve Fukušimě aktivně budují nové jaderné zdroje na Slovensku (Mochovce), ve Finsku (Olkiluoto 3, OL3) a ve Francii (Flamanville). V pokročilé fázi přípravy se nacházejí projekty v Mad’arsku (Paks), Rumunsku (Cernavodă), Velké Británii (Hinkley Point C, HPC) a Finsku (Hanhikivi) a připravuje se jaderná výstavba nejen $\mathrm{v}$ ČR, ale i v Litvě, Nizozemsku, Bulharsku, Polsku, a opět i na Slovensku a v Británii.

Jedním z hlavních sporných témat veřejné debaty o jaderné energii, jež je v současnosti jedním z nejdůležitějších determinantů jejího budoucího rozvoje ne-li př́mo tím nejdůležitějším -, je enormně nákladné financování výstavby jaderných elektráren (Černoch a Zapletalová 2015; Osička a Černoch 2017; Jirušek et al. 2015: 343-351) V této souvislosti se v posledních letech v oblasti financování JE prosazuje celá řada inovativních př́stupů (IAEA 2015: 55), které se vyznačují zapojováním stále širšího okruhu subjektů do investičního procesu, možnostmi variabilního rozložení rizik jaderné výstavby a používáním 
specifických finančních schémat. Přesto je této problematice v odborné literatuře věnována jen skromná pozornost. Téměr žádná pozornost pak není věnována hlubší analýze možných hrozeb a rizik, která se $\mathrm{k}$ používaným způsobům financování váží a která představují jeden z jejich nejzásadnějších aspektů. Tento př́spěvek si klade za úkol alespoň základním způsobem tuto mezeru vyplnit; jeho cílem je proto vymezení a kategorizace způsobů (modelů) financování výstavby jaderných elektráren a identifikace potenciálních hrozeb $z$ těchto finančních modelů vyplývajících.

Článek je rozdělen do tř́ sekcí. V první diskutujeme současný stav výzkumu a dosavadní literaturu, jež se financováním JE zabývá. Poté přistoupíme ke kategorizaci modelů financování na základě předem definovaných kritérií a jejich následnému popisu. Po analýze modelů financování završíme text $\mathrm{v}$ poslední kapitole určením souvisejících hrozeb a rizik.

\section{Literatura a současný stav výzkumu}

$\mathrm{Na}$ rozdíl od hojně reflektovaných témat investičních nákladů, ekonomické nebo environmentální konkurenceschopnosti jádra, rizik jaderných projektů, územně vztaženého rozvoje JE, prrípadně nedořešeného konce palivového cyklu (Dančák et al. 2015a; Dančák et al. 2015b), se téma financování nových jaderných elektráren v hlubší podobě vyskytuje zř́idka. George (2007) se zaměřil na financování nových jaderných zdrojů, kde nachází značné obtíže a navrhuje pomocnou aplikaci alternativních metod financování. Kennedy (2007) provedl analýzu nákladů a prínosů nových jaderných zdrojů ve Velké Británii, která pro jádro vyznívá př́innivě. Finon a Roques (2008) se jako jedni z prvních komplexně zabývali analýzou finančních modelů používaných při financování jaderných elektráren. Díky velmi dynamickému vývoji této oblasti však jejich př́íspěvek trpí značnou zastaralostí. Campbell a Haried (2009) se v části své stati věnují aspektům jaderných projektů, které determinují ochotu investorů k jejich tržnímu financování. Tyto aspekty spatřují v rizicích spojených s jadernými projekty a také ve struktuře financování, které ovšem věnují jen malou pozornost. Grubler (2010) se zabývá rozmachem francouzského jaderného potenciálu, prričemž detailně dokumentuje eskalaci konstrukčních nákladů a problematizuje tak tezi o snižování nákladů skrze získávání zkušeností a know-how. Mirrlees-Black (2011) adresuje problémy, jimž financování nových jaderných kapacit čelí, a navrhuje vznik globálního fondu, prostřednictvím něhož by byly jaderné projekty financovány. Ruuska et al. (2013) analyzují řízení velkých investičních projektů jaderných elektráren a navrhují konkrétní kroky ke zlepšení projektového managementu. Joyner (2013), ač těžiště jeho článku leží v právní oblasti, do značné míry úspěšně identifikuje nové trendy financování JE, ačkoliv jeho kategorizace je poměrně hrubá a rizika způsobů financování opomíjí. Rimšaitė (2013) analyzuje možnosti 
Contract for Difference $(\mathrm{CfD})^{3}$ při financování jaderných elektráren. Keppler a Cometto (2015) sice na financování JE narážejí, avšak soustředí se spíše na hodnocení efektivnosti investic do jádra a př́slušný projektový management. Blyth, McCarthy a Gross (2015) zkoumají financování britského energetického sektoru jako celku pohledem vztahu energetického a finančního sektoru na pozadí nezbytnosti značných kapitálových investic, které ohrožují tradiční model fungování energetických společností. Pokud je autorům známo, v českém jazyce $\mathrm{k}$ předmětné problematice př́íspěvky prakticky neexistují.

Významná část této nevelké množiny příspěvků spočívá $\mathrm{v}$ publikačních výstupech několika mezinárodních organizací, především Mezinárodní agentury pro atomovou energii (IAEA), Světové jaderné asociace (WNA) a Organizace pro hospodářskou spolupráci a rozvoj (OECD). Publikace, které uvádějí klasifikaci způsobů financování, však trpí několika společnými nedostatky. Jedním z nejvážnějších je značná roztř́ššenost, která vedla $\mathrm{k}$ situaci, $\mathrm{v}$ níž neexistuje ani vzdáleně jednotná klasifikace, ale pouze zcela nekoherentní výčet a popis $\mathrm{v}$ praxi aplikovaných finančních modelů, plus množina principů, jimiž se různé podoby financování vyznačují. Neexistuje rozlišení, co lze považovat za model, co za pouhou variantu uvnitř určitého modelu, ani co finančním modelem již není. Některé modely se vyznačují takovou mírou flexibility, že se prolínají s jinými, a hranice mezi nimi není vủbec jednoznačná. Problémem stojícím v pozadí tohoto stavu je i stanovení př́liš hrubých klasifikačních kritérií, nebo jejich úplná absence, z níž plynou i omezené možnosti vyvozovat potřebná zobecnění.

\section{Financování výstavby jaderných zdrojů}

Výstavba jaderné elektrárny či dostavba nových bloků v rámci stávající elektrárny je kapitálově náročnou investicí a v prvé řadě komerčním projektem společností obvykle fungujících podle tržních principů, které musejí kalkulovat s rozumnou návratností investovaných prostředků, od čehož se také financování takové investice odvijí. Typický průběh financování jaderné elektrárny je charakteristický značným objemem vlastního kapitálu potřebného $\mathrm{v}$ raných fázích výstavby na straně energetické společnosti, či alespoň financováním s pomocí cizího kapitálu z její rozvahy. Tento požadavek, obzvláště při stavbě více bloků, mnohdy vede $\mathrm{k}$ vytvoření konsorcia firem. Projekt je financován po fázích a náklady financování tak odrážejí pouze riziko spojené s danou fází. S postupující výstavbou jsou riziková místa překonávána, celkové riziko projektu se snižuje a přibližují se první výnosy. Následkem toho se zlevňuje dluhové financování a může tak docházet ke změnám kapitálové struktury a refinancování dřívějších úvěrů (IAEA 2008: 8;

\footnotetext{
${ }^{3}$ CfD je bilaterální smlouva, na jejímž základě producent elektrické energie získává za vyráběnou energii fixní částku navýšenou o rozdíl mezi dohodnutou jednotkovou cenou a aktuální spotovou cenou, za níž se elektřina v daný okamžik obchoduje na trhu (Rimšaitė 2013: 459).
} 
WNA 2012: 33). K refinancování může dojít i vícekrát. Celý koncept se nazývá fázové financování (phased financing) a může se prolínat s libovolným finančním modelem (Barkatullah 2014: 9).

$\mathrm{K}$ tomu, abychom mohli provést kategorizaci finančních modelů, je velmi vhodné nejprve stanovit jednoznačná kritéria, na jejichž základě budou modely rozlišovány. V této práci jsme se rozhodli použít dvě klasifikační kritéria. Hlavním kritériem je typ subjektu, který je zadavatelem stavby nové elektrárny. Vedlejší kritérium tkví v okruhu subjektů, které investici typicky financují, bez ohledu na to, zda k tomu užívají kapitálu vlastního nebo cizího. Základním smyslem kategorizace je, aby hodnota kritérií u žádné dvojice modelů nebyla totožná. $\mathrm{Na}$ základě daných kritérií v následující tabulce č. 1 definujeme typizované modely financování výstavby nových jaderných elektráren:

Tabulka č. 1: Typologie finančních modelů podle kritérií zadavatele a okruhu investorù $^{4}$

\begin{tabular}{|l|l|l|}
\hline Finanční model & Zadavatel & Okruh investorů \\
\hline $\begin{array}{l}\text { 1. Přímé financování } \\
\text { energetickou společností }\end{array}$ & $\begin{array}{l}\text { státní/soukromá energetická } \\
\text { společnost }\end{array}$ & zadavatel \\
\hline $\begin{array}{l}\text { 1.B. Power Purchase } \\
\text { Agreement }\end{array}$ & $\begin{array}{l}\text { státní/soukromá energetická } \\
\text { společnost }\end{array}$ & zadavatel \\
\hline \hline 2. Projektové financování & státní/soukromá společnost & special purpose vehicle \\
\hline \hline 3. Public Private Partnership & stát & soukromé společnosti, stát \\
\hline $\begin{array}{l}\text { 4. Investice velkoodběratelů } \\
\text { elektřiny }\end{array}$ & $\begin{array}{l}\text { konsorcium soukromých } \\
\text { společností }\end{array}$ & $\begin{array}{l}\text { konsorcium soukromých } \\
\text { společností }\end{array}$ \\
\hline \hline 5. Dodavatelské financování & státní/soukromá společnost & zadavatel, dodavatel \\
\hline \hline $\begin{array}{l}\text { 6. Build, Own, Operate, } \\
\text { Transfer }\end{array}$ & státní/soukromá společnost & dodavatel, cizí stát \\
\hline \hline 7. Financování cizím státem & stát & cizí stát \\
\hline
\end{tabular}

Zdroj: autoři.

Uvedené kategorie si s pomocí dostupných zdrojů na dalších řádcích blíže popíšeme; následující text vychází ze syntézy několika zdrojů, které s uvedenými metody financování pracují (Barkatullah 2014; Finon 2008; IAEA 2008: s. 3-8; IAEA 2009: 19-26; IAEA 2014: 49-52; IAEA 2015: 55-58; IFNEC 2014: 13-22; Joyner 2013: 6-11; OECD 2011: 94-97; WNA 2012: 33-34).

\footnotetext{
${ }^{4} \mathrm{~V}$ tabulce i dále $\mathrm{v}$ textu preferujeme české ekvivalenty názvů $\mathrm{v}$ angličtině. $\mathrm{V}$ př́padech, kdy není ustálen český přepis a je obvyklé používat názvy či zkratky v angličtině, se držíme anglických originálů.
} 
1. Primé financování energetickou společností. Mnohé společnosti obzvláště v Evropě a Asii jsou integrovány např́č celým elektroenergetickým sektorem a disponují dostatečně velkou bilanční sumou, která jim umožňuje financovat i natolik kapitálově náročné projekty, jakými jsou jaderné elektrárny; zároveň mají díky své úvěruschopnosti takový př́stup na kapitálové trhy, který jim umožňuje zde získat dostatečný objem peněžních prostředků $\mathrm{k}$ investici za přijatelných úrokových podmínek. Energetická společnost má nad projektem plnou kontrolu, ale také plnou zodpovědnost za veškerá rizika.

V rámci EU př́mé financování nalezneme u probíhající stavby nového bloku jaderné elektrárny ve francouzském Flamanville a dostavby dvou bloků slovenských Mochovcí. Obě stavby financují národní energetické společnosti (EdF, resp. Slovenské elektrárne), byt' v prŕpadě Slovenska většinově v soukromých rukou.

1.B. Power Purchase Agreement (PPA). PPA ztělesňuje finanční schéma, jež lze pro jeho charakteristiku zahrnout pod model př́mého financování, avšak svými specifiky si zasluhuje být vyčleněno zvlášt jako jeho podtyp. Financování investice se principiálně neliší, nicméně po zprovoznění elektrárny začíná hrát velkou roli stát. Prostřednictvím PPA se stát přímo či skrze státní podnik po stanovenou dobu zavazuje odebírat produkci elektrárny, odebírat ji za dohodnutou cenu, nebo obojí. Tato dohoda je uzavřena na začátku projektu, před finálním rozhodnutím o investici, a jejím cílem je motivovat energetickou společnost $\mathrm{k}$ investičnímu rozhodnutí faktickou garancí určité výnosnosti investice. Projekt je pomocí tohoto mechanismu chráněn před tržními riziky, kterými jsou zejména nedostatečná poptávka po elektřině nebo její nízká tržní cena. Praktickou realizací tohoto schématu je CfD.

Průkopnickým pŕíkladem financování typu PPA v EU je již schválená stavba třetího bloku britské elektrárny Hinkley Point. Ta bude společným dílem EdF a čínské CGN. Britská vláda se $\mathrm{v}$ rámci $\mathrm{CfD}$ zavázala kromě záruky za úvěr garantovat výkupní cenu elektřiny z nově postaveného zdroje po dobu 35 let na dvou možných úrovních. První z nich ve výši 89,5 GBP/MWh se uplatní v případě, že EdF bude úspěšně rozvíjet projekt elektrárny Sizewell C, což je další plánovaný zdroj na britském území s reaktory EPR, který by tak firmě umožnil efektivně rozložit FOAK náklady mezi oba projekty. $\mathrm{V}$ opačném př́padě bude uplatněna garantovaná výkupní cena 92,5 GBP/MWh.

2. Projektové financováni (Project Finance) ${ }^{5}$. Spočivá ve vytvoření účelové entity, tzv. special purpose vehicle (SPV) skupinou zúčastněných společností, která projekt

5 Termín „Project Finance“, který jsme do češtiny přeložili jako „projektové financováni““, je třeba vyjasnit. „Project Finance“ v anglicky mluvících zemích představuje financování dlouhodobé 
od počátku financuje převážně dluhově, jejím jediným aktivem je nová elektrárna a jediným budoucím pŕíjmem přijmy z prodeje elektrriny. Dluhové financování skýtá společnostem stojícím za SPV výhodu vyšší finanční páky, protože vlastní kapitál vkládají až v pozdějších fázích projektu a jejich ostatní aktiva nejsou do té doby př́padným krachem projektu ohrožena, jako je tomu u prímého financování. ${ }^{6}$ Zásadním problémem tohoto modelu je získání velkého objemu kapitálu na finančních trzích za akceptovatelnou cenu, což ovšem může být vyřešeno poskytnutím státní záruky za úvěr poskytnutou hostitelským státem nebo státní agenturou podpory exportu (ECA). Státní záruka snižuje úvěrové riziko dlužníka, což by mělo vyústit ve zlevnění dluhového financování. Záruka za úvěry se může principiálně vyskytovat i u některých dalších finančních modelů, kde do projektu vstupuje cizí kapitál získaný na finančních trzích.

Znaky projektového financování vykazoval záměr dostavby elektrárny Temelín, který byl však po zrušení tendru na dodavatele v roce 2014 uložen $\mathrm{k}$ ledu. Z existujících projektů se tento typ financování vyskytuje u dostavby rumunské elektrárny Cernavodă, na níž se kromě rumunského vlastníka významně podílí čínský partner CGN.

3. Partnerstvi verejnébo a soukromébo sektoru (Public Private Partnership, PPP). PPP se funkčně neliší od běžných projektů financovaných pomocí PPP. Může mít podobu vládou vyhlášeného zadávacího řízení na výběr privátní společnosti či konsorcia na vybudování, spolufinancování a provoz daného počtu jaderných elektráren. Společnost či konsorcium po uvedení elektrárny do provozu inkasují přijmy z prodeje elektřiny. Umístění a použitá technologie může být zvolena zadavatelem, avšak větši počet totožných elektráren umožní rozložit náklady na aplikaci technologie (tzv. first-of-a-kind costs, FOAK costs) na všechny bloky a snížit tak jednotkové náklady na blok. PPP se v rámci EU v současnosti u žádného projektu s reálnými obrysy neuplatňuje.

4. Investice velkoodbèrateliu elektriny (tæv. mankala model). Investiční náklady na elektrárnu nese konsorcium významných odběratelů elektřiny a podniků veřejných služeb v hostitelské zemi. Financování probíhá jak pomocí vlastního kapitálu konsorcia, tak dluhově. Dluhové financování zde podobně jako u projektového financování př̀evládá. Větší množství podílejících se společností slouží kromě př́sunu dodatečného kapitálu k diversifikaci rizika projektu. Konsorcium posléze vlastní elektrárnu, hradí její provozní náklady, ale zároveň získává elektřinu za nákladovou cenu. Tuto velmi levnou elektřinu oproštěnou od tržních výkyvư dále

infrastruktury, průmyslových projektů a veřejných služeb, v němž dochází ke splácení dluhů pomocí cash flow generovaného projektem po jeho uvedení do chodu (Investopedia n.d.).

${ }^{6}$ Tento princip je znám pod pojmem limited recourse finance.

${ }^{7}$ Hostitelským státem rozumíme ten, na jehož území má vzniknout nová jaderná elektrárna. 
používá pro své vlastní potřeby a prodává distributorům. Konsorcium také funguje jako záruka dlouhodobé a stabilní poptávky po její produkci.

Tento model, který je typický pro finskou jadernou energetiku, je aplikován při financování stavby třetího bloku elektrárny Olkiluoto a rovněž je s ním počítáno v projektu elektrárny Hanhikivi. Na obou projektech se podílejí různá konsorcia - TVO a Fennovoima, prričemž obě jsou složena z odlišných podílnických společností.

5. Dodavatelské financování (vendor finance). Dodavatelské financování může nabývat mnoha různých podob. $V$ tomto modelu se na financování stavby elektrárny podílí samotná dodavatelská společnost, jež ji zároveň buduje. Finanční spoluúčast vzniká prostřednictvím třech možných mechanismů: zprostředkování úvěru od „spřízněné“ instituce, poskytnutí dodavatelského úvěru nebo prímého kapitálového vstupu do projektu. Při pouhém zprostředkování úvěru dodavatel zajistí úvěr např́klad od propojené banky nebo ECA. Druhý mechanismus tvoří poskytnutí většinou krátkodobého dodavatelského úvěru, který se již projeví v rozvaze dodavatele. Kapitálový vstup pak znamená poskytnutí vlastního kapitálu, který dodavateli není splacen, avšak ten jeho prostřednictvím participuje na cash flow, které elektrárna po svém zprovoznění generuje. Dodavatel se tím stává spoluvlastníkem elektrárny a je silně zainteresován na celkovém úspěchu projektu. Podobně jako PPP se ani dodavatelské financování u žádného aktuálního jaderného projektu v EU nevyskytuje.

6. Build, Own, Operate, Transfer (BOOT). Jedná se o natolik svébytný typ dodavatelského financování, že jej vymezujeme jako samostatný model. Dodavatel postaví, financuje, vlastní a provozuje elektrárnu scílem pokrýt investiční a provozní náklady prodejem elektřiny za předem stanovenou cenu distribučním společnostem, dosáhnout prodejem na určitou marži, a tím nakonec i celkového zisku. Nakonec bud' elektrárnu předá do rukou lokální společnosti, nebo si ji dlouhodobě ponechá (model se pak nazývá jen BOO, nebot’ k transferu dochází až po uplynutí značné doby). BOOT není v současné době v EU př́i stavbě jaderných zdrojů využíván.

7. Financováni cið̨ím státem (government-to-government financing). Jak napovídá anglický originál, tento typ financování spočívá v poskytnutí bilaterální mezivládní půjčky státem dodavatele státu hostitelskému. Detaily podmínek půjčky mohou být upraveny předběžnou mezivládní dohodou. Z poskytnutého úvěru je hrazena většina nákladů a úvěr je amortizován po uvedení elektrárny do provozu z výnosů z prodeje elektřiny. Tento model financování může přinést zemím s omezenými zdroji a know-how (např́klad těm, jež staví svůj první jaderný zdroj) v oblasti JE dostatečný objem finančních prostředků i zkušeností, dále může upevnit a rozšíríit 
vzájemné bilaterální vztahy a ekonomické vazby a prohloubit spolupráci v dalších odvětvích. Nezbytným předpokladem úspěšného fungování tohoto modelu je oboustranná motivace aktérů zvolit tento způsob financování.

Exemplárním príkladem tohoto finančního modelu je výstavba dvou nových bloků mad’arské elektrárny Paks. Rozhodnutí o výstavbě předcházela dohoda nejvyšších politických představitelů Mad’arska a Ruska o poskytnutí úvěru mad’arské straně, který by měl pokrýt 80 \% investičních nákladů. V únoru 2017 nabídl Vladimir Putin Mad’arsku přepracování smlouvy a 100\% financování.

Dané modely se $\mathrm{v}$ praxi mohou ve svých nuancích mírně odlišovat či kombinovat prvky více modelů; uvedený výčet však slouží jako teoretické uchopení možných zpo̊sobů financování. Základním předpokladem životaschopného finančního modelu zůstává schopnost vypořádat se s hrozbami a riziky jaderných projektů, což je klíčem k vybudování důvěry investorů a jejich udržitelnému financování.

$\mathrm{Na}$ základě uvedených modelů můžeme identifikovat různé typy subjektů ekonomicky účastných kompletního investičního procesu výstavby jaderné elektrárny. K těm patří zadavatel zakázky, investoři a poskytovatelé kapitálu, dodavatelský řetězec (dodavatelé a subdodavatelé), vlastník elektrárny, stát a jiné zainteresované státy. Téměř vždy se stává, že jeden subjekt plní v investičním procesu více rolí, typicky zadavatel zakázky bývá současně investorem, prípadně je zadavatelem zakázky státní podnik či prrímo stát. Jiné státy bývají neprrímou součástí investičního procesu prostřednictvím svých státních a polostátních institucí, které slouží jako dodavatelé nebo investoři. Jak je ovšem z popisu modelů patrné, vyskytují se i jiné kombinace rolí jednoho subjektu.

\section{Hrozby vyplývající z finančních modelů}

K identifikaci hrozeb typických pro jednotlivé modely budeme postupovat po krocích. V prvním kroku provedeme diferenciaci modelů podle rolí, jež v každém modelu zastávají vybraní aktéri investičního procesu. Zároveň zvolíme kritéria, pomocí nichž budeme schopni rozlišit roli klíčových aktérů $\mathrm{v}$ rámci jednotlivých modelů, poněvadž to nám velmi usnadní a zpřehlední práci s hrozbami každého modelu, nebot' u většiny $z$ nich lze postřehnout jistou proměnu hrozeb v závislosti na charakteru a působení klíčových subjektů investičního procesu. Další kroky budou spočívat v identifikaci faktorů naznačujících přítomnost určité hrozby a následné kategorizaci hrozeb. Poté dojde k uvedení výčtu konkrétních hrozeb a celý postup završíme jejich prířazením $\mathrm{k}$ vnitřně diferencovaným finančním modelům. Celý postup vychází z provedeného popisu fungování a analýzy jednotlivých finančních modelů.

V rámci prvního kroku je pro finální určení hrozeb smysluplné zohlednit štěpení subjektů investičního procesu podle určitých kritérií. Z celé řady možných př́stupů $\mathrm{k}$ této otázce jsme za nejvhodnější zvolili rozčlenění subjektu hlavního 
(majoritního) investora podle dvou kritérií. Jedním z nich je typ investora podle jeho vlastníka (státní/soukromý), druhým kritériem pak vlastnická př́slušnost investora (domácí/zahraničnî), jak znázorňuje následující tabulka č. 2.

Tabulka č. 2: Přehled možných variant finančních modelů podle kritérií typu a vlastnické př́íslušnosti majoritního investora

\begin{tabular}{|c|c|c|c|c|c|}
\hline Model & Zadavatel & $\begin{array}{l}\text { Majoritní } \\
\text { investor }\end{array}$ & $\begin{array}{l}\text { Vlastník } \\
\text { elektrárny }\end{array}$ & $\begin{array}{l}\text { Typ } \\
\text { majoritního } \\
\text { investora }\end{array}$ & $\begin{array}{l}\text { Vlastnická } \\
\text { příslušnost } \\
\text { investora }\end{array}$ \\
\hline \multirow{4}{*}{$\begin{array}{l}\text { 1. Přímé } \\
\text { financování }\end{array}$} & \multirow{4}{*}{ státní/soukromý } & \multirow{4}{*}{ zadavatel } & \multirow{4}{*}{ zadavatel } & \multirow{2}{*}{ státní } & domácí \\
\hline & & & & & zahraniční \\
\hline & & & & \multirow{2}{*}{ soukromý } & domácí \\
\hline & & & & & zahraniční \\
\hline \multirow{4}{*}{ 1.B PPA } & \multirow{4}{*}{ státní/soukromý } & \multirow{4}{*}{ zadavatel } & \multirow{4}{*}{ zadavatel } & \multirow{2}{*}{ státní } & domácí \\
\hline & & & & & zahraniční \\
\hline & & & & \multirow{2}{*}{ soukromý } & domácí \\
\hline & & & & & zahraniční \\
\hline \multirow{4}{*}{$\begin{array}{l}\text { 2. Project } \\
\text { Finance }\end{array}$} & \multirow{4}{*}{ státní/soukromý } & \multirow{4}{*}{ SPV } & \multirow{4}{*}{ SPV } & \multirow{2}{*}{ státní } & domácí \\
\hline & & & & & zahraniční \\
\hline & & & & \multirow{2}{*}{ soukromý } & domácí \\
\hline & & & & & zahraniční \\
\hline \multirow{4}{*}{ 3. PPP } & \multirow{4}{*}{ stát } & \multirow{4}{*}{$\begin{array}{l}\text { zadavatel/ } \\
\text { soukromý }\end{array}$} & \multirow{4}{*}{ soukromý } & \multirow{2}{*}{ státní } & domácí \\
\hline & & & & & \\
\hline & & & & \multirow{2}{*}{ soukromý } & domácí \\
\hline & & & & & zahraniční \\
\hline \multirow{3}{*}{ 4. Mankala } & \multirow{3}{*}{ soukromý } & \multirow{3}{*}{$\begin{array}{l}\text { konsorcium } \\
\text { zadavatelů }\end{array}$} & \multirow{3}{*}{$\begin{array}{l}\text { konsorcium } \\
\text { zadavatelů }\end{array}$} & & \\
\hline & & & & soukromý & domácí \\
\hline & & & & soukromy & \\
\hline \multirow{4}{*}{$\begin{array}{l}\text { 5. Vendor } \\
\text { Finance }\end{array}$} & \multirow{4}{*}{ státní/soukromý } & \multirow{4}{*}{ zadavatel } & \multirow{4}{*}{ zadavatel } & stótní & domácí \\
\hline & & & & statnı & zahraniční \\
\hline & & & & & domácí \\
\hline & & & & soukromý & zahraniční \\
\hline & & & & státní & \\
\hline 6. BOOT & státní/soukromý & dodavatel/ & dodavatel & & zahraniční \\
\hline 7. Financování & & & zadavatel/ & státní & zahraniční \\
\hline cizím státem & stát & cizí stát & státní & & \\
\hline
\end{tabular}

Zdroj: autoři. 
Majoritním investorem máme na mysli entitu, která se na financování investice podílí z více než $50 \%$. Nerozlišujeme přitom, zda investici financuje kapitálem vlastním nebo cizím. Některé modely (PPP, dodavatelské financovánî) umožňují vznik takového investorského rozložení, kdy o žádném subjektu nelze prohlásit, že by byl majoritním investorem. U jiných (projektové financovánî) může být struktura majoritního investora natolik spletitá, že se $\mathrm{v}$ př́padě převahy státních firem $\mathrm{v}$ tomto subjektu nedá ř́ci, který stát je dominantní. Tuto okrajovou a problematicky uchopitelnou množinu př́padů si můžeme dovolit $\mathrm{v}$ rámci vnitřní diferenciace modelů opomenout.

Za státní subjekt považujeme takový, v němž má stát nadpoloviční, a tedy rozhodující podíl, bez ohledu na to, zda je tento podíl př́mý, či zdali vertikální vlastnická hierarchie směrující ve výsledku ke státu obsahuje i jiné subjekty. V jaderném průmyslu není výskyt státních podniků nikterak neobvyklý. Dochází i k situacím, kdy se firma na první pohled tváří jako privátní společnost, ovšem v síti vlastnických vztahů se nakonec ukáže jako nepřímo kontrolovaná státem. Ostatní subjekty pojímáme za soukromé, tedy i ty, v nichž sice má podíl stát, ten ale není kontrolní. Domácím subjektem rozumíme takový, jehož konečným vlastníkem je bud' sám hostitelský stát, nebo je zde registrován. Pokud tomu tak není, jedná se o subjekt zahraniční. Jestliže v tabulce zmiňujeme „stát“, máme jím striktně na mysli stát hostitelský. V textu o něm hovoříme jako o „státu“ nebo „hostitelském státu“. Jakýkoliv jiný stát v tabulce označujeme za „cizí stát“ a v textu jej rovněž nazýváme jako „cizí stát“ nebo „jiný stát“. Konečně, zatmavené pole značí eventualitu, která se v praxi z logiky fungování modelů nevyskytuje, a proto s ní dále nepracujeme.

Nyní se zaměříme na hrozby specifické pro jednotlivé typy finančních modelů. Hrozeb a z nich plynoucích rizik příznačných pro jaderné projekty je celá řada a lze je rozčlenit do různých skupin, např́klad coby rizika technická, ekonomická, institucionální, bezpečnostní a podobně (podrobněji viz např́ílad Chumak a Shchepetina 2014: 144-149; Finon a Roques 2008: 250-256; Osička et al. 2014: 199-204). Tato oblast je již poměrně uceleně zpracována, a to včetně analýzy konkrétních hrozeb. Kde však podobná analýza dosud chybí, jsou rizika a hrozby vyplývající prímo $z$ aplikace určitého modelu financování jaderné elektrárny. Tato rizika a hrozby se mohou vztahovat na různé zainteresované subjekty, z mezinárodně-politického hlediska se však nejrelevantnější jeví za potenciálně ohrožený subjekt zvolit stát, což je však v dostupné literatuře rovněž zrrídkavým jevem. Cílem další analýzy je tedy odhalit rizika a hrozby plynoucí hostitelskému státu, přičemž rizika a hrozby, které nejsou důsledkem zvolení určitého finančního modelu, stejně jako rizika a hrozby pro ostatní subjekty zde ponecháváme stranou.

K určení hrozeb a následných rizik je podstatné identifikovat jejich determinanty, které označíme za rizikové faktory. Část z nich se nám podařilo určit pomocí analýzy investičního procesu a jeho klíčových aktérů (viz 
tabulka č. 2). Jedná se o zadavatele, majoritního investora, vlastníka elektrárny, typ majoritního investora a jeho vlastnickou př́slušnost. Dané faktory však zdaleka nejsou vyčerpávající. Mezi aktéry investičního procesu jsme zařadili také poskytovatele kapitálu, kteři by mohli tvořit rizikový faktor. Tato skupina je striktně odlišná od investorů projektu, přičemž do ní spadají banky, jiné úvěrové instituce a také subjekty finančního trhu investující do korporátních dluhopisů a obdobných investičních instrumentů, které emitují investoři jaderných projektů za účelem získání finančních prostředků. Poskytovatelé kapitálu, byt' jimi půjčené prostředky jsou pro realizaci investice mnohdy nezbytné, se tak investičního procesu účastní pouze skrze investory a z tohoto do̊vodu jsou jako samostatný rizikový faktor nevyhovující.

Jiného názoru jsme u dodavatele stavby, kterým rozumíme hlavního dodavatele, jenž podepisuje kontrakt se zadavatelem, a jeho úkolem je dodávka parního systému elektrárny. Dodavatel se na financování investice mưže různými způsoby zcela autonomně podílet, proto jej považujeme za dalši rizikový faktor. Dodavatelem může být $\mathrm{v}$ některých př́padech více firem sdružených do konsorcia. Zbytek dodavatelského řetězce reprezentovaný subdodavateli se však z pohledu financování investice netěší velkému významu a pro analýzu hrozeb není př́liš relevantní.

Role hostitelského státu $\mathrm{v}$ realizaci nukleárních projektů a různé možnosti zapojení státu do financování naopak relevanci nepostrádají, což nás vede $\mathrm{k}$ př̀svědčení, že zahrnutí role státu mezi rizikové faktory je zcela nezbytné. Kromě hostitelského státu se u některých modelů může na financování projektu různou měrou podílet také jiný stát. Mimo finanční podíl jiného státu považujeme za důležité také identifikovat př́padný vztah mezi daným státem a dodavatelem, protože nám to umožní snáze postihnout možnou proměnu hrozeb odvíjející se od rozdílných forem tohoto vztahu. Podíl cizího státu na financování a jeho propojení s dodavatelem tedy pojímáme za dva samostatné rizikové faktory, čímž současně výčet rizikových faktorů uzavíráme.

Riziko ve financích lze definovat jako míru nebezpečí, s níž se skutečné výsledky našeho jednání budou nepř́iznivě odchylovat od výsledků očekávaných. Kategorizace rizika v tomto oboru se však pro tento př́spěvek nejeví vhodná. Jak je tedy možné vymezit a kategorizovat riziko v mezinárodních vztazích, což je vzhledem $\mathrm{k}$ cíli textu prŕhodnější? V prvé řadě je třeba upozornit na odlišnou terminologii, kdy riziko ve financích je v kontextu mezinárodních vztahů chápáno jako hrozba. Podle české bezpečnostní terminologie (Zeman 2002) je vztah mezi rizikem a hrozbou stanoven tak, že hrozba je primární, nezávisle existující fenomén s potenciálem ohrozit chráněnou hodnotu, zatímco riziko je pojmem druhotným, plynoucím z hrozby, chápáno de facto jako míra hrozby (Zeman 2002: 55-58; Janošec 2010: 48) To nás oklikou vrací k dřívějšímu ekonomickému definování rizika jako míry nebezpečí. Nahrazení termínu „nebezpečí“ výrazem „hrozba“ je zcela adekvátním krokem (Zeman 2002: 55), 
jímž jsou navíc harmonicky propojeny mezinárodně-politické a ekonomické vymezení hrozby a rizika.

Při kategorizaci rizik se jeví jako vhodné použít sektorové dělení. Abychom však mohli určovat rizika, je z logiky věci nejdříve nutné kategorizovat hrozby. Precizně řečeno tedy identifikujeme hrozby, z nichž teprve poplynou určitá bezpečnostní rizika. Je však zapotřebí se zamyslet nad tím, zda zvolení nějakého finančního modelu může př́mo vést ke vzniku hrozeb relevantních pro všechny sektory bezpečnosti. Se stejnou definicí hrozeb a rizik pracuje i tzv. Kodaňská škola, jež konceptualizuje bezpečnost v rámci mezinárodních vztahů (Buzan, Wæver a de Wilde 2005: 16-18, 32-34). Protože souhlasíme s nutností radikální reformy bezpečnostních studií (podrobněji Waisová 2003: 17-30) rozšiřující spektrum nejen referenčních objektů, ale také zdrojů hrozeb, využíváme dále sektorové pojetí bezpečnosti.

Buzan a kol. vztahují pojem bezpečnosti k pěti sektorům: vojenskému, environmentálnímu, ekonomickému, společenskému a politickému. Vojenský sektor podle naznačeného dělení zahrnuje vztahy násilného donucení, politický sektor vztahy autority, vládnoucích a ovládaných a uznání; ekonomický sektor je vymezen obchodními, výrobními a finančními vztahy; společenský sektor pak vztahy kolektivní identity; a konečně environmentální sektor tvoří vztah mezi lidským jednáním a biosférou. Zatímco o relevanci hrozeb pro ekonomický a politický sektor nemáme důvod pochybovat, u zbývajících třech sektorů tomu tak není. Byt' jejich ohrožení $\mathrm{v}$ důsledku zvolení určitého finančního modelu nelze a priori vyloučit, jedná se o natolik atypickou možnost, že s ní dále nebudeme pracovat. $\mathrm{Na}$ základě uvedených skutečností rozdělíme rizika pouze do dvou skupin - na ekonomická a politická.

Po identifikaci rizikových faktorů a kategorizaci hrozeb nyní přistoupíme již k uvedení výčtu konkrétních hrozeb (tabulka 3), z nichž plynou daná rizika. U všech jaderných projektů je nezbytné individuálně posoudit konkrétní mezinárodně-politické, ekonomické a jiné relevantní okolnosti, které mohou zapříčinit, že naplnění potenciálu určité hrozby není možné důvodně očekávat a nebude $z$ ní tedy plynout žádné riziko.

Hrozby si na následujících řádcích prriblížíme. V souvislosti s některými finančními modely, u nichž stát nebo státní podnik obdrží na jadernou investici úvěr, může hrozit jeho platební neschopnost či povinnost za určitých podmínek tento úvěr splácet dřive, než začne nová elektrárna generovat výnosy z prodeje elektřiny. Při zakotvení výkupní ceny elektřiny daleko před samotným započetím stavby se po spuštění elektrárny do provozu může ukázat, že elektřiny na trhu je nadbytek a její cena je mnohem nižší než vládou dohodnutá výkupní cena. Z těchto hrozeb vyplývá pro stát ekonomické riziko. Větší skupina hrozeb se týká platební neschopnosti zúčastněných subjektů. Některé z těchto i dalších hrozeb se zcela nevyhnutelně prolínají, nicméně žádné se nepřekrývají zcela a pro dosažení přesnějšího pochopení problematiky je účelné je od sebe oddělovat. Hrozba 
platební neschopnosti nestátních subjektů na první pohled nemusí působit dojmem, že by z ní pro stát mělo vyplývat ekonomické riziko. Tato možnost však může způsobit zdržení (a tím automaticky prodražení), zastavení nebo dokonce úplný nezdar celého projektu. O tom, že ohrožení stavby jaderné elektrárny implikuje pro stát riziko, není pochyb, nebot' ve hře může být kromě těžkostí s budoucím zajištěním spolehlivých dodávek elektřiny také splnění klimatických cílů, a to nejen u zemí EU. Ve stejném duchu působí i hrozby nedostatečné diversifikace zdrojů a kapitálu, nedosažení minimalizace investičních nákladů a nedostatečné kapitálové síly soukromých investorů, které ve výsledku zvyšují pravděpodobnost vzniku problémů s investicí. Př́liš̌ velká finanční páka může učinit financování projektu neúnosně nákladným s obdobnými důsledky jako výše zmíněné hrozby. Vlastnictví elektrárny v rukou soukromého subjektu se pak odlišuje od platební neschopnosti tohoto vlastníka skutečností, že množství a cena produkované elektřiny nejsou pod kontrolou státu. Může tak dojít k situaci, kdy zájmy státu nebudou v souladu se zájmy vlastníka elektrárny, ten např́klad omezí produkci a vyvolá tím nutnost nalézt k pokrytí poptávky po energii jiné zdroje.

\section{Tabulka č. 3: Vyjádření konkrétních hrozeb vztažených ke kategoriím rizika}

\begin{tabular}{|c|c|}
\hline Ekonomická & $\begin{array}{l}\text { - neschopnost státu/státní firmy splácet úvěr } \\
\text { - povinnost státu splácet úvěr před uvedením elektrárny do } \\
\text { provozu } \\
\text { - vznik technologické závislosti } \\
\text { - nedostatečná diversifikace zdrojů kapitálu } \\
\text { - povinnost hradit neopodstatněně vysoké vyrovnávací platby za } \\
\text { produkovanou elektřinu vzhledem k situaci na trhu } \\
\text { - platební neschopnost subjektu, za jehož úvěr se stát zaručil } \\
\text { - platební neschopnost majoritního soukromého investora } \\
\text { - platební neschopnost majoritního zahraničního investora } \\
\text { - platební neschopnost soukromého vlastníka elektrárny } \\
\text { - vlastnictví elektrárny v rukou soukromého subjektu } \\
\text { - nedosažení minimalizace investičních nákladů } \\
\text { - př́liš velká finanční páka projektu } \\
\text { - nedostatečná kapitálová síla soukromých investorů }\end{array}$ \\
\hline Politická & $\begin{array}{l}\text { - zvýšení závislosti na jiném státu } \\
\text { - snížení interdependence vůči jinému státu } \\
\text { - zvýšení citlivosti na uplatňování politického vlivu } \\
\text { - snížení energetické bezpečnosti (EB) } \\
\text { - vyšetřování ze strany Evropské komise (EK) } \\
\text { - nesoulad s energetickými a politickými zájmy EU } \\
\text { - nevýhodné podmínky bilaterální spolupráce } \\
\text { - vlastnictví elektrárny v rukou zahraničního státního subjektu }\end{array}$ \\
\hline
\end{tabular}

Zdroj: autoři. 
Zvýšení závislosti, př́padně zesílení asymetrie interdependence ve vztahu $\mathrm{k}$ jinému státu $\mathrm{v}$ př́padě jeho angažmá na jaderném projektu působí jako spojené nádoby $\mathrm{v}$ závislosti na charakteru dané dyády. Tyto hrozby mohou doplňovat a katalyzovat nevýhodně nastavené podmínky bilaterální spolupráce. Obdobnou působnost sledujeme také u potenciálně zvýšené citlivosti na uplatňování politického vlivu, přičemž ten nemusí uplatňovat pouze zúčastněný cizí stát, nýbrž i jiné státy nebo nadnárodní subjekty a korporace. Jak dokládají pŕíklady typické i pro další sektory energetiky, všechny tyto hrozby implikují politické riziko (viz např́klad Kratochvíl a Tichý 2013; Osička et al. 2016; Osička a Ocelík 2017). Vyšetřování ze strany EK a nesoulad s energetickými a politickými zájmy EU jsou hrozbami specifickými pro státy Unie s potenciálem zkomplikovat postavení daného státu na komunitární rovině.

Faktem zůstává, že zařazení některých hrozeb pod danou kategorii rizik může vyvolat určitou polemiku. Zároveň by však žádné přiřazení hrozby nemělo být natolik kontroverzní, aby bylo možno považovat její přiřazení druhé kategorii za opodstatněnější. Př́ikladem může být hrozba vzniku technologické závislosti, která v prŕpadě silného provázání dodavatele a jeho domovského státu může vyvolat i riziko politické. Možnost snížení EB může nabývat nejrůznějších podob mimo jiné v závislosti na tom, jak EB definujeme. Konečně vlastnictví elektrárny v rukou zahraničního státního subjektu jsme zařadili pod rizika politická, poněvadž skrze tento subjekt může jeho státní vlastník prosazovat své politické zájmy na úkor státu hostitelského. Po provedení vnitřní diferenciace finančních modelů, identifikaci rizikových faktorů, zvolení rizikových kategorií a konečném výčtu hrozeb tedy přistoupíme $\mathrm{k}$ jejich prířazení jednotlivým modelům v následující shrnující tabulce č. 4 . 
Tabulka č. 4: Rizika a hrozby finančních modelů

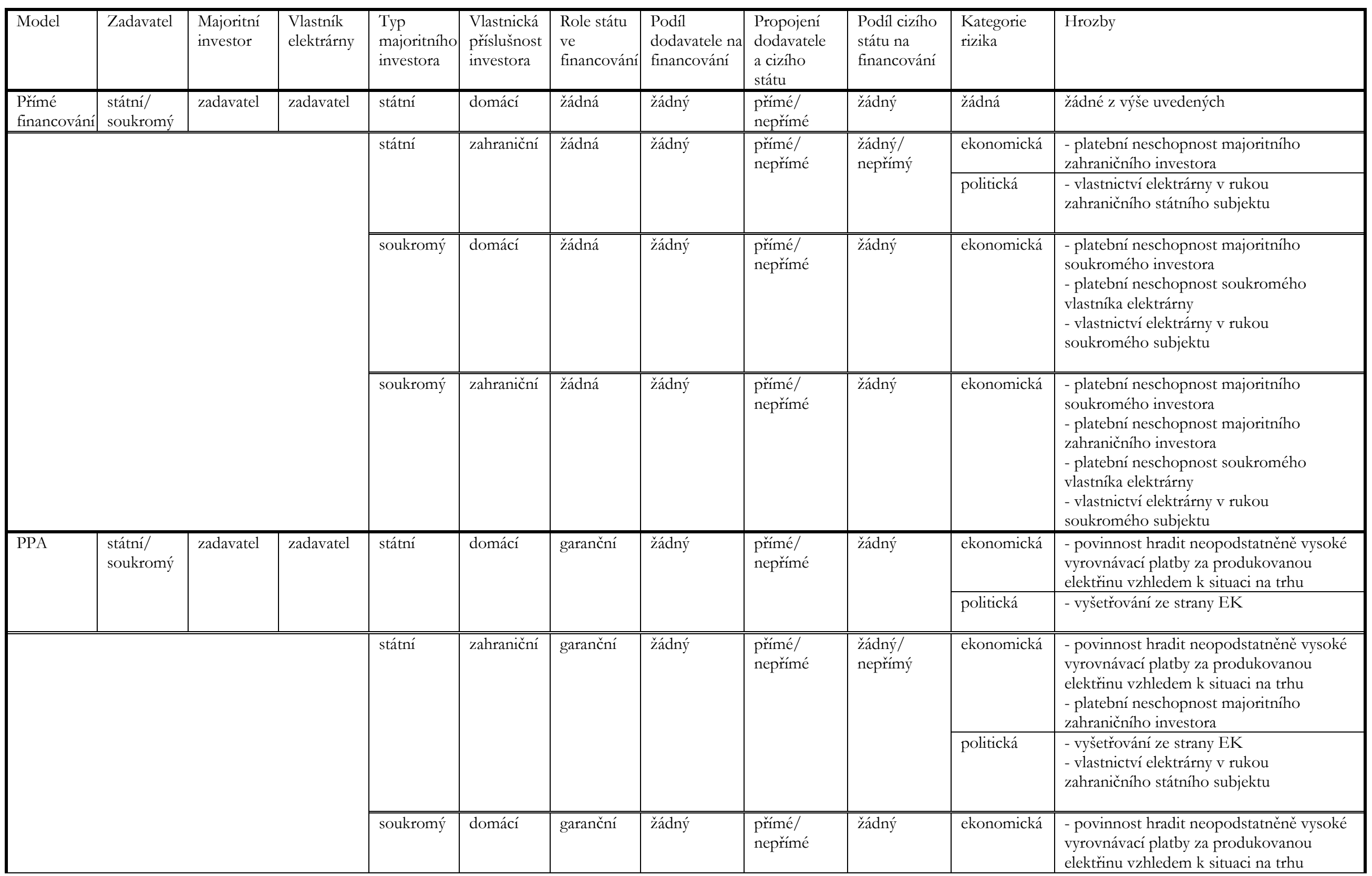




\begin{tabular}{|c|c|c|c|c|c|c|c|c|c|c|c|}
\hline & & & & & & & & & & & $\begin{array}{l}\text { - platební neschopnost majoritního } \\
\text { soukromého investora } \\
\text { - vlastnictví elektrárny v rukou } \\
\text { soukromého subjektu }\end{array}$ \\
\hline & & & & & & & & & & politická & - vyšetřování ze strany EK \\
\hline & & & & soukromý & zahraniční & garanční & žádný & $\begin{array}{l}\text { príímél } \\
\text { neprímé }\end{array}$ & žádný & ekonomická & $\begin{array}{l}\text { - povinnost hradit neopodstatněně vysoké } \\
\text { vyrovnávací platby za produkovanou } \\
\text { elektrúnu vzhledem k situaci na trhu } \\
\text { - platební neschopnost majoritního } \\
\text { soukromého investora } \\
\text { - platební neschopnost majoritního } \\
\text { zahraničního investora } \\
\text { - vlastnictví elektrárny v rukou } \\
\text { soukromého subjektu }\end{array}$ \\
\hline & & & & & & & & & & politická & - vyšetř̌ování ze strany EK \\
\hline Model & Zadavatel & $\begin{array}{l}\text { Majoritní } \\
\text { investor }\end{array}$ & $\begin{array}{l}\text { Vlastník } \\
\text { elektrárny }\end{array}$ & $\begin{array}{l}\text { Typ } \\
\text { majoritního } \\
\text { investora }\end{array}$ & $\begin{array}{l}\text { Vlastnická } \\
\text { př́slušnost } \\
\text { investora }\end{array}$ & $\begin{array}{l}\text { Role státu } \\
\text { ve } \\
\text { financování }\end{array}$ & $\begin{array}{l}\text { Podíl } \\
\text { dodavatele na } \\
\text { financování }\end{array}$ & $\begin{array}{l}\text { Propojení } \\
\text { dodavatele } \\
\text { a cizího } \\
\text { státu }\end{array}$ & $\begin{array}{l}\text { Podíl cizího } \\
\text { státu na } \\
\text { financování }\end{array}$ & $\begin{array}{l}\text { Kategorie } \\
\text { rizika }\end{array}$ & Hrozby \\
\hline $\begin{array}{l}\text { Project } \\
\text { Finance }\end{array}$ & $\begin{array}{l}\text { státní/ } \\
\text { soukromý }\end{array}$ & SPV & SPV & státní & domácí & $\begin{array}{l}\text { žádná/ } \\
\text { garanční }\end{array}$ & žádný & $\begin{array}{l}\text { príímé/ } \\
\text { nepríímé }\end{array}$ & žádný & ekonomická & $\begin{array}{l}\text { - povinnost hradit neopodstatněně vysoké } \\
\text { vyrovnávací platby za produkovanou } \\
\text { elektrrinu vzhledem k situaci na trhu } \\
\text { - platební neschopnost subjektu, za jehož } \\
\text { úvěr se stát zaručil } \\
\text { - př́liliš velká finanční páka projektu }\end{array}$ \\
\hline & & & & & & & & & & politická & - vyšetřování ze strany EK \\
\hline & & & & státní & zahraniční & $\begin{array}{l}\text { žádná/ } \\
\text { garanční }\end{array}$ & žádný & $\begin{array}{l}\text { príímél } \\
\text { neprímé }\end{array}$ & $\begin{array}{l}\text { žádný/ } \\
\text { neprímý }\end{array}$ & ekonomická & $\begin{array}{l}\text { - povinnost hradit neopodstatněně vysoké } \\
\text { vyrovnávací platby za produkovanou } \\
\text { elektrrinu vzhledem k situaci na trhu } \\
\text { - platební neschopnost subjektu, za jehož } \\
\text { úvěr se stát zaručil } \\
\text { - př́lišs velká finanční páka projektu }\end{array}$ \\
\hline & & & & & & & & & & politická & $\begin{array}{l}\text { - vyšetřování ze strany EK } \\
\text { - vlastnictví elektrárny v rukou } \\
\text { zahraničního státního subjektu } \\
\end{array}$ \\
\hline & & & & soukromý & domácí & $\begin{array}{l}\text { žádnál } \\
\text { garanční }\end{array}$ & žádný & $\begin{array}{l}\text { príímél } \\
\text { neprímé }\end{array}$ & žádný & ekonomická & $\begin{array}{l}\text { - povinnost hradit neopodstatněně vysoké } \\
\text { vyrovnávací platby za produkovanou } \\
\text { elektřinu vzhledem k situaci na trhu } \\
\text { - platební neschopnost subjektu, za jehož } \\
\text { úvěr se stát zaručil } \\
\text { - vlastnictví elektrárny v rukou } \\
\text { soukromého subjektu } \\
\text { - př́liš velká finanční páka projektu }\end{array}$ \\
\hline & & & & & & & & & & politická & - vyšetřování ze strany EK \\
\hline
\end{tabular}




\begin{tabular}{|c|c|c|c|c|c|c|c|c|c|c|c|}
\hline & & & & soukromý & zahraniční & $\begin{array}{l}\text { žádná/ } \\
\text { garanční }\end{array}$ & žádný & $\begin{array}{l}\text { prímé/ } \\
\text { nepřímé }\end{array}$ & žádný & $x^{2}$ & $\begin{array}{l}\text { - povinnost hradit neopodstatněně vysoké } \\
\text { vyrovnávací platby za produkovanou } \\
\text { elektřinu vzhledem k situaci na trhu } \\
\text { - platební neschopnost subjektu, za jehož } \\
\text { úvěr se stát zaručil } \\
\text { - vlastnictví elektrárny v rukou } \\
\text { soukromého subjektu } \\
\text { - př́liš velká finanční páka projektu }\end{array}$ \\
\hline & & & & & & & & & & politická & - vyšetřování ze strany EK \\
\hline PPP & stát & $\begin{array}{l}\text { zadavatel/ } \\
\text { soukromý }\end{array}$ & soukromý & státní & domácí & majoritní & možný & $\begin{array}{l}\text { prímé/ } \\
\text { nepřímé }\end{array}$ & žádný & ekonomická & $\begin{array}{l}\text { - platební neschopnost soukromého } \\
\text { vlastníka elektrárny } \\
\text { - vlastnictví elektrárny v rukou } \\
\text { soukromého subjektu }\end{array}$ \\
\hline & & & & soukromý & domácí & minoritní & možný & $\begin{array}{l}\text { prímé/ } \\
\text { nepř́mé }\end{array}$ & žádný & ekonomická & $\begin{array}{l}\text { - platební neschopnost majoritního } \\
\text { soukromého investora } \\
\text { - platební neschopnost soukromého } \\
\text { vlastníka elektrárny } \\
\text { - vlastnictví elektrárny v rukou } \\
\text { soukromého subjektu }\end{array}$ \\
\hline & & & & soukromý & zahraniční & minoritní & možný & $\begin{array}{l}\text { prímé/ } \\
\text { nepřímé }\end{array}$ & žádný & "ekonomická & $\begin{array}{l}\text { - platební neschopnost majoritního } \\
\text { soukromého investora } \\
\text { - platební neschopnost majoritního } \\
\text { zahraničního investora } \\
\text { - platební neschopnost soukromého } \\
\text { vlastníka elektrárny } \\
\text { - vlastnictví elektrárny v rukou } \\
\text { soukromého subjektu }\end{array}$ \\
\hline Model & $\overline{\text { Zadavatel }}$ & $\begin{array}{l}\text { Majoritní } \\
\text { investor }\end{array}$ & $\begin{array}{l}\text { Vlastník } \\
\text { elektrárny }\end{array}$ & \begin{tabular}{l|} 
Typ \\
majoritního \\
investora
\end{tabular} & $\begin{array}{l}\text { Vlastnická } \\
\text { příslušnost } \\
\text { investora }\end{array}$ & $\begin{array}{l}\text { Role státu } \\
\text { ve } \\
\text { financování }\end{array}$ & $\begin{array}{l}\text { Podíl } \\
\text { dodavatele na } \\
\text { financování }\end{array}$ & $\begin{array}{l}\text { Propojení } \\
\text { dodavatele } \\
\text { a cizího } \\
\text { státu }\end{array}$ & $\begin{array}{l}\text { Podíl cizího } \\
\text { státu na } \\
\text { financování }\end{array}$ & $\begin{array}{l}\text { Kategorie } \\
\text { rizika }\end{array}$ & Hrozby \\
\hline Mankala & soukromý & $\begin{array}{l}\text { konsorcium } \\
\text { zadavatelů }\end{array}$ & $\begin{array}{l}\text { konsorcium } \\
\text { zadavatelů }\end{array}$ & soukromý & domácí & žádná & možný & $\begin{array}{l}\text { prímé/ } \\
\text { neprímé }\end{array}$ & žádný & ekonomická & $\begin{array}{l}\text { - platební neschopnost majoritního } \\
\text { soukromého investora } \\
\text { - platební neschopnost soukromého } \\
\text { vlastníka elektrárny } \\
\text { - vlastnictví elektrárny v rukou } \\
\text { soukromého subjektu } \\
\text { - prríliš velká finanční páka projektu } \\
\text { - nedostatečná kapitálová síla soukromých } \\
\text { investorů }\end{array}$ \\
\hline
\end{tabular}




\begin{tabular}{|c|c|c|c|c|c|c|c|c|c|c|c|}
\hline \multirow[t]{2}{*}{$\begin{array}{l}\text { Vendor } \\
\text { Finance }\end{array}$} & \multirow[t]{2}{*}{$\begin{array}{l}\text { státní/ } \\
\text { soukromý }\end{array}$} & \multirow[t]{2}{*}{ zadavatel } & \multirow[t]{2}{*}{ zadavatel } & \multirow[t]{2}{*}{ státní } & \multirow[t]{2}{*}{ domácí } & \multirow[t]{2}{*}{$\begin{array}{l}\text { žádná/ } \\
\text { garanční }\end{array}$} & \multirow[t]{2}{*}{ minoritní } & \multirow[t]{2}{*}{$\begin{array}{l}\text { prímé/ } \\
\text { neprímé }\end{array}$} & \multirow[t]{2}{*}{$\begin{array}{l}\text { žádný/ } \\
\text { neprímý }\end{array}$} & ekonomická & $\begin{array}{l}\text { - vznik technologické závislosti } \\
\text { - platební neschopnost subjektu, za jehož } \\
\text { úvěr se stát zaručil }\end{array}$ \\
\hline & & & & & & & & & & politická & $\begin{array}{l}\text { - zvýšení citlivosti na uplatňování } \\
\text { politického vlivu }\end{array}$ \\
\hline & & & & státní & zahraniční & $\begin{array}{l}\text { žádná/ } \\
\text { garanční }\end{array}$ & minoritní & $\begin{array}{l}\text { prímé/ } \\
\text { nepřímé }\end{array}$ & $\begin{array}{l}\text { žádný/ } \\
\text { neprímý }\end{array}$ & ekonomická & $\begin{array}{l}\text { - vznik technologické závislosti } \\
\text { - platební neschopnost subjektu, za jehož } \\
\text { úvěr se stát zaručil }\end{array}$ \\
\hline & & & & & & & & & & politická & $\begin{array}{l}\text { - zvýšení citlivosti na uplatňování } \\
\text { politického vlivu } \\
\text { - vlastnictví elektrárny v rukou } \\
\text { zahraničního státního subjektu }\end{array}$ \\
\hline & & & & soukromý & domácí & $\begin{array}{l}\text { žádná/ } \\
\text { garanční }\end{array}$ & minoritní & $\begin{array}{l}\text { prímé/ } \\
\text { nepřímé }\end{array}$ & $\begin{array}{l}\text { žádný/ } \\
\text { neprímý }\end{array}$ & ekonomická & $\begin{array}{l}\text { - vznik technologické závislosti } \\
\text { - platební neschopnost subjektu, za jehož } \\
\text { úvěr se stát zaručil } \\
\text { - platební neschopnost majoritního } \\
\text { soukromého investora } \\
\text { - platební neschopnost soukromého } \\
\text { vlastníka elektrárny } \\
\text { - vlastnictví elektrárny v rukou } \\
\text { soukromého subjektu }\end{array}$ \\
\hline & & & & & & & & & & politická & $\begin{array}{l}\text { - zvýšení citlivosti na uplatňování } \\
\text { politického vlivu }\end{array}$ \\
\hline & & & & soukromý & zahraniční & $\begin{array}{l}\text { žádná/ } \\
\text { garanční }\end{array}$ & minoritní & $\begin{array}{l}\text { prímé/ } \\
\text { nepřímé }\end{array}$ & $\begin{array}{l}\text { žádný/ } \\
\text { neprímý }\end{array}$ & ekonomická & $\begin{array}{l}\text { - vznik technologické závislosti } \\
\text { - platební neschopnost subjektu, za jehož } \\
\text { úvěr se stát zaručil } \\
\text { - platební neschopnost majoritního } \\
\text { soukromého investora } \\
\text { - platební neschopnost majoritního } \\
\text { zahraničního investora } \\
\text { - platební neschopnost soukromého } \\
\text { vlastníka elektrárny } \\
\text { - vlastnictví elektrárny v rukou } \\
\text { soukromého subjektu }\end{array}$ \\
\hline & & & & & & & & & & politická & $\begin{array}{l}\text { - zvýšení citlivosti na uplatňování } \\
\text { politického vlivu }\end{array}$ \\
\hline
\end{tabular}




\begin{tabular}{|c|c|c|c|c|c|c|c|c|c|c|c|}
\hline \multirow[t]{2}{*}{ BOOT } & \multirow[t]{2}{*}{$\begin{array}{l}\text { státní/ } \\
\text { soukromý }\end{array}$} & \multirow[t]{2}{*}{ dodavatel } & \multirow[t]{2}{*}{ dodavatel } & \multirow[t]{2}{*}{ státní } & \multirow[t]{2}{*}{ zahraniční } & \multirow[t]{2}{*}{ žádná } & \multirow[t]{2}{*}{ majoritní } & \multirow[t]{2}{*}{ přímé } & \multirow[t]{2}{*}{$\begin{array}{l}\text { možný/ } \\
\text { nepřímý }\end{array}$} & ekonomická & $\begin{array}{l}\text { - vznik technologické závislosti } \\
\text { - nedostatečná diversifikace zdrojů kapitálu }\end{array}$ \\
\hline & & & & & & & & & & politická & $\begin{array}{l}\text { - zvýšení závislosti na jiném státu } \\
\text { - snížení interdependence vǔči jinému státu } \\
\text { - zvýšení citlivosti na uplatňování } \\
\text { politického vlivu } \\
\text { - snížení energetické bezpečnosti } \\
\text { - vlastnictví elektrárny v rukou } \\
\text { zahraničního státního subjektu }\end{array}$ \\
\hline Model & Zadavatel & $\begin{array}{l}\text { Majoritní } \\
\text { investor }\end{array}$ & $\begin{array}{l}\text { Vlastník } \\
\text { elektrárny }\end{array}$ & $\begin{array}{l}\text { Typ } \\
\text { majoritního } \\
\text { investora }\end{array}$ & $\begin{array}{l}\text { Vlastnická } \\
\text { prríslušnost } \\
\text { investora }\end{array}$ & $\begin{array}{l}\text { Role státu } \\
\text { ve } \\
\text { financování }\end{array}$ & $\begin{array}{l}\text { Podíl } \\
\text { dodavatele na } \\
\text { financování }\end{array}$ & $\begin{array}{l}\text { Propojení } \\
\text { dodavatele } \\
\text { a cizího } \\
\text { státu } \\
\end{array}$ & $\begin{array}{l}\text { Podíl cizího } \\
\text { státu na } \\
\text { financování }\end{array}$ & $\begin{array}{l}\text { Kategorie } \\
\text { rizika }\end{array}$ & Hrozby \\
\hline \multirow[t]{2}{*}{$\begin{array}{l}\text { Financován } \\
\text { cizím } \\
\text { státem }\end{array}$} & \multirow[t]{2}{*}{ stát } & \multirow[t]{2}{*}{ cizí stát } & \multirow[t]{2}{*}{$\begin{array}{l}\text { zadavatel/ } \\
\text { státní }\end{array}$} & \multirow[t]{2}{*}{ státní } & \multirow[t]{2}{*}{ zahraniční } & \multirow[t]{2}{*}{ možná } & \multirow[t]{2}{*}{ možný } & \multirow[t]{2}{*}{ přímé } & \multirow[t]{2}{*}{ majoritní } & ekonomická & $\begin{array}{l}\text { - neschopnost státu/státní firmy splácet } \\
\text { úvěr } \\
\text { - povinnost státu splácet úvěr před } \\
\text { uvedením elektrárny do provozu } \\
\text { - vznik technologické závislosti } \\
\text { - nedostatečná diversifikace zdrojů kapitálu } \\
\text { - nedosažení minimalizace investičních } \\
\text { nákladů }\end{array}$ \\
\hline & & & & & & & & & & politická & $\begin{array}{l}\text { - zvýšení závislosti na jiném státu } \\
\text { - snížení interdependence vǔči jinému státu } \\
\text { - zvýšení citlivosti na uplatňování } \\
\text { politického vlivu } \\
\text { - snížení energetické bezpečnosti } \\
\text { - vyšetřování ze strany EK } \\
\text { - nesoulad s energetickými a politickými } \\
\text { zájmy EU } \\
\text { - nevýhodné podmínky bilaterální } \\
\text { spolupráce }\end{array}$ \\
\hline
\end{tabular}

Zdroj: autoři. 
Jak jsme již zmínili dříve, některé modely financování se vyznačují velkou flexibilitou. Hodnoty rizikových faktorů uváděné v tabulce jsou pro jednotlivé modely typické, přesto nelze vyloučit, že některý faktor může nabýt hodnoty, kterou neuvádíme. Chápání faktorů zadavatele, majoritního investora, vlastníka elektrárny, typu majoritního investora a jeho vlastnické př́slušnosti včetně hodnot, kterých mohou tyto faktory nabývat, jsme vymezili výše v textu (viz tabulku č. 2). Dalším z rizikových faktorů je role státu ve financování, která může nabývat hodnot žádná, možná, minoritní, majoritní a garanční. První čtyři jmenované spolu navzájem logicky souvisejí a chápeme je jako přímý finanční podíl státu na investici. Hodnoty, kterých tento podíl může nabývat, shrnuje následující tabulka č. 5. Shodná logika významu hodnot platí i pro faktor podílu dodavatele na financování.

\section{Tabulka č. 5: Finanční podíl subjektu na investici v \% a jeho slovní vyjádření}

\begin{tabular}{|l|c|c|c|}
\hline Podíl & 0 & $(0 ; 50>$ & $(50 ; 100>$ \\
\hline \multirow{4}{*}{} & žádný & & \\
\cline { 2 - 4 } & \multicolumn{2}{|c|}{ možný } & \\
\cline { 2 - 4 } & & minoritní & majoritní \\
\cline { 2 - 4 } & & & \\
\hline
\end{tabular}

Zdroj: autoři.

Žádný podíl očekávatelně odpovídá $0 \%$, minoritní podíl se nachází v intervalu od 0 do $50 \%$ včetně a majoritní podíl pak od 50 \% výše. Možný podíl znamená bud' žádný, nebo minoritní podíl. Faktor role státu může nabývat navíc jedné specifické hodnoty - garanční. Ta je vyjádřením záruky za úvěr nebo kontraktu PPA, jak byly popsány u př́slušných finančních modelů.

Propojení dodavatele a cizího státu rozlišujeme dvojí - př́mé a nepřímé. Př́mé propojení symbolizuje bud' př́mou, nebo nepřímou majetkovou kontrolu státu nad konkrétním dodavatelem. Nepř́mé propojení reprezentuje všechny ostatní možnosti, kdy daná společnost a stát, v němž je registrována, nejsou většinově majetkově propojeny. Stát však přesto mủže být na výsledcích firmy zainteresován, což dává najevo např́klad nabídkou financování prostřednictvím exportní agentury. Podíl cizího státu na financování, je-li přítomen, rovněž rozdělujeme na prímý, kde se cizí stát podílí na financování přímo či prostřednictvím své vládní agentury, a neprímý, kde stát disponuje majoritní majetkovou účastí v majoritním investorovi nebo dodavateli, který se podílí na financování projektu. Možný či majoritní podíl cizího státu na financování vykazuje hodnoty uvedené v tabulce č. 5 .

Hrozby přiřazené jednotlivým vnitřně diferencovaným modelům považujeme za typické. Lze namítnout, že některé hrozby, z nichž plynou ekonomická rizika, 
by se měly vyskytovat u všech modelů. Kupřikladu platební neschopnost některého $z$ investorů hrozí v zásadě ve všech př́padech. Takový př́stup by však postrádal logiku, nebot' smyslem některých modelů, čímž v tomto partikulárním příkladu máme na mysli projektové financování, je přizváním většího množství investorů toto riziko naopak účinně diversifikovat (prostřednictvím diversifikace investičního rizika), přestože zcela eliminovat jej není možné. Tímto všezahrnujícím př́stupem bychom setřeli hranice mezi některými modely a připravili se o patřičně hluboký vhled do rizik i jen neprŕliš odlišných modelů.

\section{Závěr}

Problematika financování nových jaderných zdrojů je v současné době z mezinárodně-politického hlediska mimořádně ožehavá. $O$ to více kontrastním dojmem pak působí zjevná absence odborných článků, které by předmětnou problematiku utř́dily a přinesly do ní tolik potřebný vhled. $V$ textu jsme popsali celkem sedm modelů. U jednoho z nich se jako opodstatněné ukázalo samostatně vymezit jeden podtyp, čímž se celkový počet modelů zvýšil na osm.

Jestliže jsme konstatovali, že neexistuje jednotná typologie finančních modelů, pro přehled typických hrozeb a rizik př́značných jednotlivým modelům to platí dvojnásob. Celý postup následující po definování modelů, který vyvrcholil přiřazením těchto hrozeb a rizik $\mathrm{k}$ modelům, byl tak odkázán na vlastní analytickou práci. Rozkladem modelů, určením zainteresovaných subjektů, jejich vzájemné provázanosti a role ve financování jsme byli schopni vymezit nejen rizikové faktory přináležející jednotlivým modelům, ale do značné míry také nabízející se hrozby a rizika z nich vyplývající. Syntéza získaných poznatků vedla ke vzniku matice finančních modelů, jejich hrozeb a rizik (viz tabulku č. 4), která bezpochyby tvoří stěžejní komponentu prríspěvku.

Z hlediska vnitřní diferenciace modelů nese nejmenší okruh hrozeb majoritní financování státním domácím subjektem. Okruh hrozeb se pak rozšiřuje přes financování státním zahraničním subjektem, soukromým domácím subjektem, až $\mathrm{k}$ financování subjektem soukromým zahraničním, $\mathrm{k}$ němuž se váže nejširší okruh hrozeb. To ukazuje na jednoznačný trend rozšiřování množiny hrozeb s rostoucím zapojením zahraničních a soukromých entit. S daným trendem souvisí i prímá úměra počtu hrozeb a podílu dodavatele na financování, která je dále umocněna prímým propojením dodavatele s jiným státem. V přinejmenším obdobně zvýšené míře pak tato prímá úměra platí pro podíl cizího státu na financování. Širší okruh hrozeb neznamená, že daný model nebo určitá jeho vnitřní konstelace je rizikovější než jiné; znamená pouze, že se u něj vyskytuje širší škála potenciálních hrozeb, která je třeba brát v úvahu. Některá z nich však mohou často splývat nebo se suvážením okolností projektu ukázat jako irelevantní. 
Př́spěvek odhalil potřebu dále rozvíjet výzkum předmětné problematiky. Mezi témata, která by si zasloužila další zpracování, patří mimo jiné optimalizovaná typologie finančních modelů, která bude lépe reflektovat jejich neustálý vývoj, například sbližování PPA a projektového financování. V neposlední řadě zmiňme, že operacionalizace tohoto výzkumu je nová a dosud jinde nevyzkoušená, nabízí se tudíž její testování a př́ípadná optimalizace na konkrétních jaderných projektech.

\section{Literatura a prameny}

Poznámka: Elektronické zdroje ověreny k 6. 2. 2017.

Barkatullah, Nadira (2014): „Identification and Discussion of Various Nuclear Power Project Finance Models." Prezentace na konferenci IFNEC Steering Group Meeting and Finance Panel, Bucharest, 9. 5. 2014. on-line https://www.ifnec.org/ifnec/upload/docs/ application/pdf/2016-02/finance_and_project_structuring_panel-

review_of_financing_models_nadira_barkatullah.pdf

Blyth, William, Rory McCarthy a Robert Gross (2015): „Financing the UK power sector: Is the money available?" Energy Policy 87(December 2015): 607-622. DOI: 10.1016/j.enpol.2015.08.028

Buzan, Barry, Ole Waever a Jaap De Wilde (2005): Bezpečnost: nový rámec pro analýru. Brno: Barrister \& Principal.

Campbell, Patricia L. a Jim Haried (2009): „Financing and Licensing Nuclear Energy Parks." Natural Resources \& Environment 24(2): 42-47.

Černoch, Filip a Veronika Zapletalová (2014): „Hinkley point C: A new chance for nuclear power plant construction in central Europe?“ Energy Policy 83(August 2015): 165-168. DOI: 10.1016/j.enpol.2015.04.002

Dančák, Břetislav, Filip Černoch, Pavla Filipská, Marek Goldbach, Romana Hanžlová, Jaromír Leichmann, Petr Ocelík, Jan Osička, Kateřina Švecová, Vojtěch Wertich, Veronika Zapletalová (2015a): Energy Infrastructure and Exploration Areas. Characteristics, Relationships, and Local Acceptance. Brno: Masarykova univerzita.

Dančák, Břetislav, Filip Černoch, Pavla Filipská, Marek Goldbach, Romana Hanžlová, Jaromír Leichmann, Petr Ocelík, Jan Osička, Kateřina Švecová, Vojtěch Wertich, Veronika Zapletalová. (2015b): Metodika aktivit geologickébo prĩzkumu a výzkumu postoju mistních komunit ve vəৃtahu k budováni energetické infrastruktury. Brno: Masarykova univerzita.

Finon, Dominique (2008): „Contractual and financing arrangements for new nuclear build in liberalised markets." Prezentace na konferenci Energy \& Climate Policy - Towards a Low Carbon Future, Salzburg, 15.-18. 9. 2008.

Finon, Dominique a Fabien Roques (2008): „Financing arrangements and industrial organisation for new nuclear build in electricity markets." Competition and Regulation in Network Industries 9(3), 247-281.

Chumak, Dmitry a Tatyana Shchepetina (2014): „Risk Classification as a Necessary Management Element in Nuclear Power Projects.“ Atomic Energy 116(2): 144-149. DOI: 10.1007/s10512-014-9831-2 
George, Glenn R. (2007): „Financing New Nuclear Capacity: Will the "Nuclear Renaissance" Be a Self-Sustaining Reaction?" The Electricity Journal 20(3): 12-20. DOI: 10.1016/j.tej.2007.02.007

Grubler, Arnulf (2010): „The costs of the French nuclear scale-up: A case of negative learning by doing.“ Energy Policy 38(9): 5174-5188. DOI: 10.1016/j.enpol.2010.05.003

IAEA (2008): Financing of nuclear power plants. Wien: IAEA Publishing.

IAEA (2009): Issues to Improve the Prospects of Financing Nuclear Power Plants. Vienna: IAEA Publishing.

IAEA (2014): Climate Change and Nuclear Power. Vienna: IAEA Publishing.

IAEA (2015): Climate Change and Nuclear Power. Vienna: IAEA Publishing.

IEA (n.d.): Statistics, on-line http://www.iea.org/statistics/

IFNEC (2014): Financing Nuclear Power Projects: New and Emerging Models, on-line https://www.ifnec.org/

Investopedia (n.d.): Project Finance, on-line http:/ /www.investopedia.com/

Janošec, Josef (2010): „Hrozba a riziko v bezpečnostní terminologii.“ In: Kolektiv autorů (eds.), Krizový management. Pardubice: Univerzita Pardubice, 40-52.

Jirušek, Martin, Tomáš Vlček, Hedvika Kod'ousková, Roger W. Robinson, Anna Leshchenko, Filip Černoch, Lukáš Lehotský, Veronika Zapletalová (2015): Energy Security in Central and Eastern Europe and the Operations of Russian State-Owned Energy Enterprises. Brno: Masarykova univerzita, on-line http://www.ceners.org/energyresearch/ceners-2015-energy-security-in-cee.pdf

Joyner, Daniel (2013): „Nuclear Power Plant Financing Post-Fukushima, and International Investment Law." Journal of World Energy Law \& Business 7(2): 1-25. DOI: 10.1093/jwelb/jwt012

Kennedy, David (2007): New nuclear power generation in the UK: Cost benefit analysis. Energy Policy 35(7): 3701-3716. DOI: 10.1016/j.enpol.2007.01.010

Keppler, Jan H., Cometto, Marco (2015): „Nuclear new build: Financing and project management." NEA News 33(1): 4-11.

Kratochvíl, Petr a Lukáš Tichý (2013): „EU and Russian discourse on energy relations.“ Energy Policy 56(May 2013), 391-406. DOI: 10.1016/j.enpol.2012.12.077

Mirrlees-Black, Jonathan (2011): „Innovation in financing new nuclear." Energy \& Environment 22(1\&2), 55-60. DOI: 10.1260/0958-305X.22.1-2.55

OECD (2011). Smart Rules for Fair Trade: 50 Years of Export Credits. Paris: OECD Publishing.

Osička, Jan, Petr Ocelík a Břetislav Dančák, (2016): „The impact of Polish unconventional production on the regional distribution of natural gas supply and transit: A scenario analysis." Energy Strategy Reviews 10(May), 1-17. DOI: 10.1016/j.esr.2016.02.001

Osička, Jan a Petr Ocelík (2017): „Natural gas infrastructure and supply patterns in Eastern Europe: trends and policies." Energy Sources, Part B: Economics, Planning, and Policy. (In press.) DOI: 10.1080/15567249.2015.1136971

Osička, Jan, Černoch, Filip (2017): „Anatomy of a black sheep: the roots of the Czech Republic's pro-nuclear energy policy. " Energy Research \& Social Science 27(May): 9-13. DOI: $10.1016 /$ j.erss.2017.02.006

Osička, Jan, Filip Černoch, Petr Ocelík a Tomáš Vlček (2014): Technicko-ekonomické aspekty energetiky. Brno: Masarykova univerzita. 
Rimšaite, Laura (2013): „Nuclear Energy Projects Financing Option With Contracts For

Difference: The Perspective From European Union State Aid Modernisation." Intellectual Economics 7(4),: 453-466. DOI: 10.13165/IE-13-7-4-04

Ruuska, Inkeri, Tuomas Ahola, Karlos Artto, Giorgio Locatelli a Mauro Mancini, (2011): „A new governance approach for multi-firm projects: Lessons from Olkiluoto 3 and Flamanville 3 nuclear power plant projects." International Journal of Project Management 29(6): 647-660. DOI: 10.1016/j.ijproman.2010.10.001

Schneider, Mycle, Antony Froggatt, Julie Hazemann, Ian Fairlie, Tadahiro Katsuta, Fulcieri Maltini, M. V. Ramana a Tomas Kåberger (2016): The World Nuclear Industry Status Report 2016. Paris, London, Tokyo: A Mycle Schneider Consulting Project, on-line http://www.worldnuclearreport.org/IMG/pdf/20160713MSC-WNISR2016V2HR.pdf

US Department of Energy (2013): Cost and Performance Baseline for Fossil Energy Plants Volume 1: Bituminous Coal and Natural Gas to Electricity. National Energy Technology Laboratory Report DOE/2010/1397, on-line https://www.netl.doe.gov/ File\%20Library/Research/Energy\%20Analysis/OE/BitBase_FinRep_Rev2a3_20130919_1.pdf

Vlček, Tomáš, Martin Jirušek a James Henderson (2015): „Risk Assessment in Construction Process in Nuclear Sector within the Central and Eastern Europe." International Journal of Energy Economics and Policy 5(2): 482-493, on-line https://www.econjournals.com/index.php/ijeep/article/viewFile/1135/654

Waisová, Šárka (2003): Současné otázky mezinárodní bezpečnosti. Dobrá Voda: Aleš Čeněk.

World Nuclear Association (2012): Nuclear Power Economics and Project Structuring. London: World Nuclear Association, on-line http://www.world-nuclear.org/uploadedFiles/ org/WNA/Publications/Working_Group_Reports/REPORT_Economics_Report\%20 (1).pdf

World Nuclear Association (2017): The Economics of Nuclear Power. London: World Nuclear Association, on-line http://world-nuclear.org/information-library/economic-aspects/ economics-of-nuclear-power.aspx

Zeman, Petr (2002): „Hrozba a riziko.“ In: Zeman, Petr (ed.), Česká beapečnostní terminologie. Brno: Masarykova univerzita a Ústav strategických studií Vojenské Akademie v Brně, 85-96.

\section{Ways of Financing the Construction of New Nuclear Power Plants and the Threats Associated with Them}

\section{SUMMARY}

Nuclear power is the second most important source of electricity in the EU, closely followed by coal. The share of nuclear energy amounts to around 900 TWh out of a total electricity output in EU countries of nearly 3,300 TWh. Nuclear energy is a controversial topic in various socio-political levels, and the acquisition of nuclear power is a demanding process in terms of technology and security, as well as financial cost. 
Despite the many associated controversies, nuclear energy is enjoying a renewed wave of interest in many EU countries. This trend is the result of several factors, including accelerating EU environmental policy, with its emphasis on reducing greenhouse gas emissions; the aging and consequent decommissioning of older nuclear power plants; and the general inability of renewable energy sources to cover electricity base load production.

One controversial topic of the current public debate on nuclear energy is at the same time one of the most important determinants of its future development: it is the enormous cost of the construction of nuclear power plants. In this context, this area has in recent years seen a number of innovative approaches that are characterized by the involvement of an ever wider range of actors in the investment process, the variable distribution of threats to the construction of nuclear facilities, and the use of specific financial schemes. Yet this issue is given only scant attention in academic literature. Almost no attention is paid to in-depth analyses of the potential threats and risks to nuclear projects, which represent one of the most fundamental issues. This paper aims to fill this gap in at least a basic way, as it aims to define and categorize ways (models) of financing the construction of nuclear power plants and identify potential threats arising from these financial models.

The construction of a nuclear power plant or new units in existing plants is a capitalintensive investment and primarily a commercial project undertaken by companies that generally operate under market principles, i.e. they count on a reasonable return on invested funds. To be able to categorize the financial models (see table below), we decided to differentiate them on the basis of two classification criteria, namely the type of entity which is the contracting authority for the construction, and the group of entities that typically fund the construction, regardless of whether they use their own or foreign capital (the group of investors).

\section{Table 1: Typology of financial models according to the contracting authority and the group of investors}

\begin{tabular}{|l|l|l|}
\hline Financial model & Contracting authority & Group of investors \\
\hline $\begin{array}{l}\text { 1. Direct financing by an } \\
\text { energy company }\end{array}$ & state/private energy company & contracting authority \\
\hline $\begin{array}{l}\text { 1.B. Power Purchase } \\
\text { Agreement }\end{array}$ & state/private energy company & contracting authority \\
\hline \hline 2. Project financing & state/private energy company & special purpose vehicle \\
\hline 3. Public Private Partnership & state & private companies, state \\
\hline $\begin{array}{l}\text { 4. Investment of major } \\
\text { electricity consumers }\end{array}$ & $\begin{array}{l}\text { consortium of private } \\
\text { companies }\end{array}$ & $\begin{array}{l}\text { consortium of private } \\
\text { companies }\end{array}$ \\
\hline \hline 5. Vendor financing & state/private energy company & contracting authority, vendor \\
\hline \hline $\begin{array}{l}\text { 6. Build, Own, Operate, } \\
\text { Transfer }\end{array}$ & state/private energy company & vendor, foreign state \\
\hline \hline 7. Financing by foreign state & state & foreign state \\
\hline
\end{tabular}


These models vary slightly in their nuances in practice; they can also be combined with one another. The presented list serves as a theoretical description of possible financing methods. The basic prerequisite for a viable financial model is the ability to deal with the threats and risks facing nuclear projects, which is the key to investor confidence and sustainable financing.

On the basis of these models, we can identify different types of entities participating financially in the complete investment process of building a nuclear power plant. These include contracting authorities, investors and capital providers, the supply chain (suppliers and subcontractors), the owner of the plant, the state, and other interested states. It almost always happens that one entity has multiple roles in the investment process; typically, the contracting authority is simultaneously an investor, or a state-owned enterprise or the state itself is the contracting authority. Other states can indirectly become a part of the investment process through their state and parastatal institutions that serve as suppliers or investors.

The threats and the associated risks specific to particular types of financial models are numerous and can be divided into different groups, e.g. technical, economical, institutional, and those relating to security, etc. Whereas these areas of threats/risks have been by themselves quite comprehensively covered in the literature, including the analysis of concrete threats, a similar analysis regarding the risks and threats stemming directly from the application of a certain model of financing nuclear power plants is still missing. These risks and threats may apply to different stakeholders; however, from the international-politics point of view, the state appears to be the most relevant entity (as the potentially most endangered one). The aim of the analysis is therefore to detect threats and risks to the host state, while leaving aside the risks and threats that are not the result of the selection of a certain financial model, as well as the risks and threats to entities other than state.

To determine the threats and the risks involved, it is essential to identify their determinants, which we understand as the risk factors. Some of them have already been identified - they are the contracting authority, the major investor, the owner of the plant, the type of investor. This list is, however, far from exhaustive. We also consider as a risk factor the main vendor (who may financially participate autonomously), and for the same reason, the host state and other participating state(s). It is also important to identify the relationship between the state and the vendor, which we understand as another risk factor.

In the definition of the threat and the risk we begin with the linkage that the threat is a primary, independently existing phenomenon with the potential to compromise the protected value, while the risk is a secondary concept, derived from the threat and perceived de facto as the measure of the threat. When categorizing risks, therefore, we use the sectoral approach to security according to the Copenhagen School of security studies. Accordingly, we consider the economic and political sectors as relevant to the study, and the classification of threats is constructed upon them. 


\section{Table 2: The expression of specific threats related to risk categories}

\begin{tabular}{|l|l|}
\hline Economic & - inability of the state / state-owned enterprise to repay the loan \\
- state's obligation to repay the loan before making the plant operational \\
- emergence of technological dependence \\
- insufficient diversification of capital sources \\
- obligation to pay unreasonably high price for the electricity produced \\
compared to the market situation \\
- insolvency of the entity to which the loan is guaranteed by the state \\
- insolvency of the major private investor \\
- insolvency of the major foreign investor \\
- insolvency of the owner of the power plant \\
- ownership of the power plant by a private entity \\
- failure to minimize investment costs \\
- the financial leverage of the project being too strong \\
- insufficient capital strength on the part of private investors \\
\hline \hline Political
\end{tabular}

We have described seven models, and one subtype, bringing the total number of financial models to eight. The smallest number of threats relates to financing by a state-owned domestic company. The number of threats relating to financing by particular entities then increases in the following order: financing by a state-owned foreign entity, financing by a private domestic company, and, finally, financing by a private foreign entity; that is, financing by private foreign entities appears to be the most perilous kind. This shows a clear correlation between the increasing engagement of foreign and private entities and increasing numbers of threats. A similar correlation was found between the number of threats and the share of the financial engagement of the vendor, which is further amplified by the direct connection of the vendor with a foreign state. Another correlation was found between the number of threats and the proportion of foreign state funding. As for specific models, direct financing exhibits the narrowest range of threats; the range of threats then expands through project financing, PPA, and PPP. A substantially increased number of threats was identified with the Mankala model, vendor financing, and BOOT. Still, however, the highest number of threats is related to financing by a foreign state.

The paper also reveals the need for further research on related topics, including, for example, an optimized typology of financial models that will better reflect their constant evolution, such as the approximation of PPA and project financing. Finally, it should be noted that the operationalization used in this study is untested elsewhere; its testing on concrete nuclear projects would be an ideal follow-up to this research. 